\title{
Active learning education in Museum
}

\author{
İrem Namli Altintas', Çiğdem Kozaner Yenigül ${ }^{2}$ \\ ${ }^{1}$ Department of Education Social Studies, Süleyman Demirel University, Turkey \\ ${ }^{2}$ Department of Education Social Studies, European Universty of Lefke, Turkey
}

\begin{tabular}{l}
\hline \hline Article Info \\
\hline Article history: \\
Received Nov 6, 2019 \\
Revised Nov 28, 2019 \\
Accepted Jan 20, 2020 \\
\hline
\end{tabular}

Keywords:

Active learning

Case study

Museum

\begin{abstract}
In this study, it was aimed to determine social studies candidates how to practice about make of use museums as a learning environment. It was tried to discuss a case, for this purpose it was used case study. The study group consisted of 19 students (12 females, 7 males) studying social studies at a public university. Participants were given museum training lasting 7 weeks and the process started with the visit of the Antalya Archeology Museum. In this study, Museum Evaluation Forms were used as data collection tools. These forms were used at two-stage. The first stage was the Pre-Museum Evaluation Form and the second stage was the Activity Evaluation Forms. Content analysis technique was used in data analysis, and the forms were examined separately and themes and categories were created. In the categories, the statements of some of the participants were given with direct quotations. As a result of the research, the expectations of the students before the museum training are divided into the categories of Learning about the use of the Museum, Historical awareness and Embodiment in the theme of Cognitive Field. In the affective main theme, it was determined that it was divided into the categories of Group Work, Contribution to Professional Knowledge and Being an Effective Citizen. In the Cognitive Field theme, the students' experiences after museum training are divided into the categories of Field Knowledge, Museum Use Learning and Creativity. In the affective Thinking, Contribution to Professional Knowledge, Permanent Learning, and Role-Playing are the categories of the affective categories. Participants stated that to make use of museum to effect on the cognitive area more effective than affective area.
\end{abstract}

This is an open access article under the CC BY-SA license.

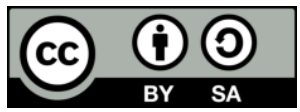

\section{Corresponding Author:}

Çiğdem Kozaner Yenigul,

Department of Education Social Studies,

European Universty of Lefke,

Lefke, Northern Cyprus TR-10 Mersin, Turkey

Email: ckozaner@eul.edu.tr

\section{INTRODUCTION}

According to the definition made by the ICOM (International Council of Museum), a museum is a non-profit, permanent institution in the service of society and its development, open to the public, which acquires, conserves, researches, communicates and exhibits the tangible and intangible heritage of humanity and its environment for the purposes of education, study and enjoyment. Since intersections between museums and communities have changed in recent years, after carefully discussing recommendations, pros and cons, prospects and potentials regarding the museum definition, the ICOM Executive Board decided that it was time to rethink and revise the existing museum definition [1]. Museums are generally considered tourist attractions and cultural heritage. At the same time, museums have a great role in education in terms of being places that provide cognitive contribution to the individual. Museums have always played an important 
role as information repositories, but they have become increasingly active distributors of information in the 20th century [2]. Museums exist with their emphasis on internal and external participation, suggesting, questioning and aiming the continuity of social development by reinforcing the sense curiosity [3]

Museum education allows people to gain experience from museum collections according to their knowledge, skills and interests and to make their own sense of these. Today, hosting exhibitions, which is among the main tasks of museums, has started to be done for educational purposes [4]. Although museums' educational role was previously limited to providing specific situations for limited groups such as children or adult tour groups, they are today used in a broader sense for hosting exhibitions, events and workshops [5]. Museum education serves the purpose of meaningfully associating the past, present and future, enabling people to recognize their own culture and different cultures with a tolerant approach, maintaining cultural heritage and developing intercultural empathy [6]. Students are taken to the center of education in educational activities in museums., Thus, effective learning occurs in student-centered education and individuals leads to change, development and more eagerness to learn. [7]

In general, learning in museums and other out-of-school settings is called informal learning, and it is qualitatively different from the activities carried out in schools. Recent developments in science of education emphasize the importance of helping people control their own learning. Since this understanding is considered important, people should learn when they understand and when they need more information [8].

There are many applications regarding the use of museums for teaching purposes, such as storytelling in painting galleries, performing drama (animation) using characters related to the works, scientific experimental workshops, poetry writing and classification in response to objects, examining their systems, developing fashion shows in indoor and outdoor spaces based on costume collections, mapping, interviewing with museum staff, and visiting museum shops or laboratories [5]. The importance of museums and art galleries comes into greater prominence when learning by doing and through experimenting is taken into consideration [9].

Education in the museum environment is based on certain learning principles.

These can be listed as follows:

a. Learning is an active process.

b. People teach while learning.

c. Meaningful learning requires a cognitive process.

d. Learning is a social activity.

e. Learning is associated with the environment.

f. Knowledge, time and experience are needed to learn.

g. Motivation is the basic element of learning [6].

New approaches in museum education are similar to innovative approaches in educational sciences. New educational practices in museums can be stated to be based on active learning and constructivist education approach, cooperative learning, and understanding of learning through invention [10]. Active learning is a process in which decision-making opportunities are given to students through activities that force them to use their mental abilities. In this process, students regularly assess themselves with the problems they face in a specific discipline and develop different skills and understanding in the handling of concepts [11]. According to another definition, it is the process of keeping students active mentally and mostly physically with activities that involve gathering information, thinking and problem-solving studies It refers to a wide range of teaching strategies that involve the student as an active participant in learning process with his/her teachers during the lesson. When using teaching strategies, the teacher is a guide that guides the student to access knowledge or acquire experience, not someone passing on knowledge. Student-centered learning is an approach in which students influence their activities, materials, and learning speed. This learning model places the student at the center of the learning process [12].

The term "active learning" and the idea of "student-centered learning" became a major area of interest among educators in the late 1970s and early 1980s. In recent years, numerous teachers, educational researchers, and cognitive psychologists have shown an interest in developing, disseminating, and evaluating teaching and learning models that offer greater opportunities for students to participate, explore, and collaborate. Advocates of active learning stressed that learning is an active process, and they developed metaphors of teaching and learning based on a "constructivist" philosophy that argued that knowledge was never transmitted only between individuals. In this process, learning is only a dynamic capacity that the student creates by using internal thought processes and influencing environmental stimuli. In other words, learning involves constructing his/her own meaning in order to understand the world he/she encounters, combining new knowledge with existing mental models. Instead of acquiring ready-to-use knowledge, students create mental representations or models of the "real world" that they use to solve problems. These representations can be created well or poorly but are constantly accessible and updated by each student, including individuals responsible for fulfilling the traditional role of the teacher [13]. 
Approaches that promote active learning focus on improving students' skills rather than transmitting knowledge and require students to do something that needs higher-level thinking (reading, discussion, writing). Active learning approaches also include the use of collaborative learning groups, a constructivist-based practice that specifically emphasizes the contribution that social interaction will make [14].

The purpose of this research is to convey the experiences related to how museums can be used as a learning environment to the Social Studies teacher candidates who will teach at the secondary school level. The study sought answers to the following questions:

a. What are the expectations of teacher candidates from the use of museums?

b. What is the effect of museum use on learning?

c. What is the effect of museum use on the affective domain?

In line with this aim, social studies teacher candidates were allowed to convey their experiences through examples of activities at the Antalya Archaeological Museum.

In this study, it was aimed to reveal different skills in the museum (skills such as critical thinking, problem solving and creative thinking by using the objects in the museum as tools) in the teaching of learning areas that include history or anthropology subjects in Social Studies course, experiences that cannot be obtained through presentation in the classroom setting. It was thought that this study would be useful for the teacher candidates who personally experienced the active learning process in museums as an educational platform.

\section{RESEARCH METHOD}

This study was designed as a case study because it aims to reveal the existing situation. In this design, teacher candidates whose perceptions about museum education were determined were considered as analysis units, and the "situation" in the case study was the resulting gains in the scope of museum education. The museum education was used in the study because it is a teaching method that facilitates the teaching of abstract subjects and creates different learning environments in order for the teacher candidates to acquire many skills and gains simultaneously and outside the classroom. In this context, in the study, what social studies teacher candidates learned throughout museum education was observed by the researcher, and as a result of this observation, what the participants learned from the activities, their self-assessments, and the emotions, thoughts and learning outcomes of the participants at the end of the activities were evaluated. In addition, a single case study was preferred as the study had a revealing status feature and for the convenience and achieving an in-depth observation. It was emphasized that the long-term assessment of the present situation was a feature of case studies [15]. In this context, the study was supported by different activities and handled with various assessment tools. In addition to this, importance was given to the causality of the case in the study, and the study environment and study group were described in depth for this purpose.

\subsection{Study group}

This study was conducted with 19 students (12 females, 7 males) studying Social Studies Teaching in a public university in 2017-2018 academic year. The study group consisted of volunteer students participating in the activities. The mean age was 21 years, and the lower and middle socio-economic groups were represented.

In this study, 4 groups were formed and named according to the activities performed.

The groupings were structured as follows:

Organizing a Ritual: Group 1 (G1)

Creating a Time Capsule: Group 2 (G2)

Organizing a Burial Ceremony: Group 3 (G3)

Reenacting a Historical Event: Group 4 (G4)

\subsection{Study process}

In this study, first of all, training was given about the activities that can be done in the museum. The training lasted approximately 7 weeks. In the 5th week of the study, an ethnographic carpet and rug museum was visited, and "pattern finding" activity was carried out within the scope of the study. With this activity, a sample activity was conducted regarding the possibility of teaching in a museum with effective participation.

The process of this study began by visiting an archaeological museum with the students, and activities were carried out through active learning in a museum using antiques from an archaeological museum. The museum contains an important part of Lycia, Pamphylia and Psidia, three ancient cultural sites 
in Anatolia, and contains as many as 5.000 artifacts. It consists of 14 exhibition halls on an area of 30.000 square meters and open-air galleries and garden where sculptures and artifacts are exhibited. For the activities, 19 students were asked to form 4 groups according to the activities, and the distribution of male and female students in these groups was taken into consideration.

According to the content of the archaeological museum, four activities were determined by the researcher. These events were:

a. Reenacting a historical event

b. Creating a Time Capsule

c. Organizing a Burial Ceremony

d. Organizing a Ritual

The activities were held in the theater hall of the museum at the end of the day.

\subsection{Data collection tools}

Qualitative and quantitative data collection tools can be used in case studies [15]. Data collection tools in this study were the activity evaluation forms. Activity assessments were conducted in 3 stages. The first stage was determined as the "Pre-Museum Education Evaluation Form", the second stage as the "Activity Evaluation Form" and the third stage as the "Self-Evaluation Form". The forms were filled out individually.

\subsubsection{Pre-museum education evaluation form}

In this form, the participants' feelings and thoughts about museum education were tried to be understood before the activities. For example, the contribution of museum education to them was tried to be addressed. Open-ended answers were given to the questions.

\subsubsection{Evaluation form}

In this form, the activities of the participants as a group were evaluated individually. At the end of the activity, after writing the name of the activity, they were asked to associate their thoughts, feelings and this activity with museum education.

\subsection{Data analysis}

Content analysis was used for the analysis of the data. Evaluation forms of the participants were evaluated separately and divided into themes and sub-themes according to the forms. Each theme created was evaluated in itself. As a result of the analysis, two main themes emerged as Cognitive Field and Affective Field. These themes were created jointly in the pre- and post-museum evaluations and then coded according to the main theme. About what form coding was performed is indicated in the results.

\subsection{Validity-reliability studies}

Validity in content analysis is related to the relevance between objectives and tools [16]. J. W. Creswell [15] recommends using two or three methods to ensure validity in the study. A. Yildirım and H. Şimşek [17] also argues that internal validity depends on the researcher in qualitative research, and therefore the way to increase internal validity should be done by different researchers in the data. One of these is the inclusion of those following the study in the analysis. In this research, too, the themes and sub-themes were validated by including more than one researcher.

In order to increase the internal validity of the study, relevant literature was reviewed and then data collection tools were prepared. The themes determined in the content analysis were tried to be determined in such a narrow way as to cover relevant concepts and to exclude irrelevant concepts. Integrity was achieved by controlling the relationship between the main themes and sub-themes.

In order to ensure the external validity of the research, the research process, namely the data collection, application and analysis phase, was tried to be explained in detail [18]. For this purpose, the research model, study group, data collection tool and data collection process were explained in detail.

\section{FINDINGS}

In this study, the results were shaped according to data collection tools. "Pre-Museum Education Evaluation Form" and "Activity Evaluation Form" were subjected to content analysis and explanations were made on the main themes. 


\subsection{Pre-museum education findings}

Result of content analysis in expression of participations were emerged two main themes in premuseum eduction: Cognitive Field and Affective Field as shown in Table 1. The Cognitive Field theme was coded as acquiring knowledge, learning the use of the museum, historical consciousness and embodying. Affective Field was coded as group work, contribution to occupational knowledge and becoming an effective citizen.

Table 1. Themes in pre-museum education

\begin{tabular}{ll}
\hline \multicolumn{1}{c}{ Cognitive Field } & \multicolumn{1}{c}{ Affective Field } \\
\hline Acquiring Knowledge & Group Work \\
Learning the Use of the Museum & Contribution to Occupational Knowledge \\
Historical Consciousness & Becoming an Effective Citizen \\
Embodying & \\
\hline
\end{tabular}

\subsubsection{Cognitive field}

\section{a. Acquiring knowledge}

Expressions in which participants thought they would acquire a formal knowledge through museums were encoded as acquiring knowledge in this study:

"I think that museums are very useful for learning our past, culture, historical events and ruins, and for developing myself" (G4, P18).

"My expectation from this activity is to see the past and establish the link between it and today" (G4, P15).

\section{b. Learning the use of the museum}

The expressions that the study group thought would enable them to learn how to use the Museums as a material before the activity were coded as learning the use of the Museum in this study:

"I've never had a chance to visit a museum with social studies awareness before. It will be an experience for me" (G2, P8).

"With this activity, the use of the museums that I think took a backseat can be learned" (G1, P2).

\section{c. Historical consciousness}

Knowing the purpose and how the materials exhibited in an archaeological museum were used in the geography where they were found have suggested to the participants that it would increase their historical awareness. Therefore, this code emerged in the pre-museum evaluation form.

"When someone speaks of a museum, old things from the past come to my mind. I think we will get ideas about the lifestyles of the people who lived before us through items on display in museums" (G2, M7).

"My expectation from this activity is to see the past and connect the past with the present. I have never been to a museum like this before and I think it will contribute to my historical consciousness" (G4, F15).

"... to perceive the discipline of history one must see the past and compare it with the present, and museums exhibit the most concrete examples of historical consciousness" (G2, F8).

\section{d. Embodying}

In the pre-museum evaluation form, the participants wrote down their expectations that the Social Studies course would become concrete. It was thought that the function of embodying subjects that were abstract in the field of history would take place in museum education.

"I think that seeing visuals of monarchs and kings that are hard to remember in history and seeing the models of their cultures will make learning easier" (G4, F14).

"As we will see it in person, I think I will provide better learning" (G3, M9).

"I think that an abstract course such as Social Studies will be embodied by museum education" $(\mathrm{G} 1, \mathrm{M} 1)$

\subsubsection{Affective field}

\section{a. Group work} the museum.

The participants expressed their expectations for the group work in their evaluations before

"My expectation from this activity is that what we can barely do individually contributes to socialization through group work as well as to individual development" (G3, M11). 


\section{b. Contribution to field knowledge}

The study group's statements on how to use museums in their fields through this activity are coded as "contribution to field knowledge" in this study:

"I think museums enable them to see courses such as History, Geography and Archaeology, which are the intermediate disciplines of Social Studies course, as more concrete" (G4, F17).

"It will be nice to learn how we, teacher candidates, will use museums as a material in the lesson and turn them into the basis of games and activities" (G1, M1).

"Since museum education is related to social studies course, I think it is important that Social Studies teacher candidates have information on this subject" (G3, M12).

\section{c. Becoming an effective citizen}

In the study group, data indicating that raising effective citizens, which is one of the main objectives of the Social Studies course, was achieved with this activity was coded as becoming an effective citizen in the study:

"If we really aim to raise effective citizens, materials to help us understand our historical, cultural elements, such as museums, should be added to education. Because such education allows the student not only to recognize his/her culture, but also to have the competence to compare it with other cultures" (G1, F3).

\subsection{Post-museum education findings}

Result of content analysis in expression of participations were emerged two main themes in postmuseum eduction: Cognitive Field and Affective Field as shown in Table 2. The cognitive field was coded as field knowledge, learning the use of the museum and creativity. The affective field was coded as empathetic thinking, contribution to occupational knowledge, permanent learning and role play.

Table 2. Themes in post-museum education

\begin{tabular}{ll}
\hline \multicolumn{1}{c}{ Cognitive Field } & Affective Field \\
\hline Field Knowledge & Empathetic Thinking \\
Learning the Use of the & Contribution to Occupational \\
Museum & Knowledge \\
Creativity & Permanent Learning \\
& Role Play \\
\hline
\end{tabular}

\subsubsection{Cognitive field}

\section{a. Field knowledge}

In the participants' thoughts and evaluations before and after the museum education, the theme that they increased their knowledge about the field of history emerged. Increasing their knowledge of the field is parallel to their conducting a research in the study process. The participants stated that they increased their field knowledge by researching the materials they found to be used in the activities, what costumes were worn under the conditions of the period, and how the ritual should be performed.

"the activity taught me what was done in old beliefs" (G3, M9).

"I think the activity has contributed to us comparing our future information with past information and learning new information" (G4, F15).

"Thanks to this activity and the museum education course, we acquired knowledge. We transferred what we saw onto paper" (G2, F6).

\section{b. Learning the use of the museum}

In the data analysis in the pre- and post-activity evaluations, statements were found regarding learning the use of the museum. Participants stated that they learned how to use the museum in the Social Studies course. It can be stated that organizing rituals, drama activities, and organizing burial activities increased their knowledge in this field.

"I have seen the benefits of learning by doing and experiencing with the activity we have put forward with on-site review of inventories on museum education"(G3, M11).

"I have learned to use the museum actively" (G4, F13).

"I have learned that the museum can be used as a material" (G1, F3).

\section{c. Creativity}

The participants stated that their creative thinking skills increased in their evaluations after the museum activities. 
"I saw that the games played improved the creativity" (G4, F14).

"It was a good activity in terms of searching, comparing, making inferences and imagining" $(\mathrm{G} 2, \mathrm{~F} 8)$.

\subsubsection{Affective field}

\section{a. Empathetic thinking}

The participants stated that they thought like the character they played after the museum activities, and this was coded in the study as empathetic thinking.

"I think this activity will make it easier to understand the constructions in that period." (G1, F5).

"The ability to see, touch and feel the statues of God and Goddess in the museum made me feel as if I were living in that period" (G4, F18).

\section{b. Contribution to occupational knowledge}

At the end of the study, the participants stated that they had learned how to use the materials in the museum in their professional lives. The fact that a teacher in the museum guiding them and introducing the materials to them gave participants the opportunity to learn teacher-student roles.

“... "I was inspired to use the activities in my career ahead" (G1, M1).

"It can be done easily with my students. By investigating the past, information is obtained about the areas of use, and comparison is made by considering today" (G2, FK).

".. I have learned that the items in the museum can be used in Social Studies classes" (G1, F4).

\section{c. Permanent learning}

The participants stated that what they learned after the museum activities was permanent.

"I saw that learning would be more permanent thanks to museum visits" (G2, M7).

"It was good to have more permanent learning and to have students have fun by having the applications done with activities, as well as to increase their participation" (G4, F17).

"Thanks to museums, I've learned that knowledge becomes permanent" (G1, F3).

\section{d. Role play}

The participants stated that museum activities improved their role-playing skills: $(\mathrm{G} 1, \mathrm{FK})$.

"This was an an activity that enhanced our role-playing skills as we reenacted an event in the past"

\section{RESULTS AND DISCUSSION}

Museums provide teacher candidates with first-hand access to resources and objects and a deeper understanding of culture, providing authentic and rich-content field experiences that go beyond traditional school-based field experiences [19]. As a result of the analysis, we can say that what the participants learned in the museum and how they learned in the cognitive domain was revealed. The cognitive domain indicates that museum activities provide permanent learning in Social Studies and History lessons. In their study [20] found that museum visits contributed to permanent learning for many of the students. Active learning approaches also include the use of cooperative learning groups, which is a constructivist practice with particular emphasis on the contribution that social interaction can make [14]. According to the data obtained from the participants' views before the activity and the workshop, we can say that the work process met their expectations in terms of solving the problems they faced with the group members during their activities at the museum. In the results, coding related to Field Knowledge, Increasing Occupational Knowledge, Learning the Use of the Museum, Permanent Learning and Creative Thinking was performed with regard to mental learning in cognitive domain. With regard to cognitive learning from these codings, it can be stated that active learning in the museum helps teacher candidates to have a professional experience, and that their knowledge with these experiences becomes permanent. Museums often provide informal education, even if they are involved in education; they are institutions that do not require attendance, do not have a curriculum, and do not question the information acquired at the end of a visit [21]. Not all educational requirements can be provided by formal education institutions; therefore, informal institutions such as museums also play an important role. Research has shown that educational experiences in the museum have a satisfactory cognitive dimension [22].

At the end of this study, social studies teacher's candidates stated that museum usage affected cognitive domains rather than affective domains. It can be stated that this is the result of teacher candidates' learning by doing and living. G. Öner [23] also found that social studies teachers think that the use of extracurricular education in history subjects will help students develop their skills such as historical empathy, 
observation and analytical thinking. V. A. Jensen [24], in his thesis on museum education and professional development partnerships, stated that motivating participants to create new ideas through concrete objects and social interaction increases their ability to create new information. Teachers should be informed about the use of museums and historical monuments in education and the facilities of museums. Studies should be conducted and encouraged for teacher candidates [25]. In this context, given the results of the studies, a great responsibility is placed on the faculties of education, especially for the effective transfer of museum education. E. Şar, et all [26] stated that through museums, the desired results in teaching would be achieved by the inclusion of education as one of the important areas of constructivist understanding of the active learning environment, and they emphasized that the Museum Education course could be included in the programs of the teacher training faculties, considering that it would support the constructivist understanding. These institutions provide teacher candidates with an alternative area for them to see how development and learning theories are used when designing and developing learning experiences for schoolage children [19]. According to another finding of the study, the participants stated that what they learned after museum activities was permanent. The reason for this can be explained as finding the application area of what they have learned [27].

It can be stated that the concentration of the museum activities on creative drama increased the awareness level of the participants in the affective field. Activities in the museum are known to increase students' affective skills [28]. Some disciplines, such as History or Fine Arts, are linked to museums in terms of their content. However, it is possible for other disciplines to connect with museums and gain an advantage in education [22]. It was thought that participants' drama work during the activities increased their skills related to role-playing. Research on the subject also supports this situation [29]. At the same time, the fact that there is no need for very special materials and that this method can be used with a planning that the teacher can make himself/herself increases the usefulness of creative drama method even more [30]. When the process of teacher candidates is evaluated, their actions such as willingness, enjoyment in activities and positive response to activities are an indication that the works carried out also affected the affective field

\section{CONCLUSION}

With the active learning activities, the teacher candidates thought that the field knowledge increased and they transferred this information using the museum as an educational environment. Therefore, active learning has not only facilitated teaching in this study, but also caused prospective teachers to gain experience on how to use museums as a learning environment. Thus, it contributed to their professional development.

\section{REFERENCES}

[1] "Creating the new museum definition: Over 250 proposals to check out," Online available from https://icom.museum/en/news/the-museum-definition-the-backbone-of-icom/, 2019.

[2] J. G. Donald, "The measurement of learning in the museum," Canadian Journal of Education, vol. 16, no. 3, pp. 371-382, 1991.

[3] C. Karadeniz and E. Özdemir, "Which museum? Change in museum studies and the new museology," Millî Folklor, vol. 120, pp. 158-169, 2018.

[4] Z. Cildir, "Reports prepared by trainers on the use of museums as an educational environment in Turkey," Journal of Folklore and Literature, vol. 20, no. 79, pp. 179-188, 2014

[5] E. Hooper-Greenhill, "The educational role of the museum," (2th ed.), London/New York:Routledge, 1999.

[6] A. İlhan, M. Artar, A. Okvuran and C. Karadeniz, "Museum training module," Ankara: MDGF UNICEF Publication, 2011.

[7] Y. Göğebakan, "The importance of using museums in education and training as alternative learning spaces," Journal of the Fine Arts Institute, vol. 40, pp. 9-41, 2018.

[8] J. Bransford, A. Brown and R. Cocking, (Eds.), "How people learn: Brain, mind, experience, and school," Washington, DC: National Academy Press, 2003.

[9] O. Dilmac, "The effect of active learning techniques on class teacher candidates' success rates and attitudes toward their museums theory and application unit in their visual arts course," Educational Sciences: Theory \& Practice, vol. 16, no. 5, pp. 1587-1618, 2016.

[10] A. Okvuran, "Growth in Turkey as a teaching drama at the museum," Education and Science, vol. 37, no. 166, pp. 170-180, 2012.

[11] Edwards, S., "Active learning in the middle grades," Middle School Journal, vol. 46(5), pp. $26-32,2015$.

[12] J. Micheal, "Where's the evidence that active learning works?" Advances in Physiology Education, vol. 30, pp. 159-167, 2006.

[13] "Active learning models \& $\quad$ approaches," $2019 . \quad$ Online available from https://wisc.pb.unizin.org/teachingwithtech/chapter/active-learning-models-approaches. 
[14] C. Brame, "Active learning," Vanderbilt University Center for Teaching, 2016. Online available from https://cft.vanderbilt.edu/active-learning/.

[15] J. W. Creswell, "Qualitative inquiry and research design: Choosing among five traditions," London: Sage Publications, 2007.

[16] N. Bilgin, "Content analysis in social sciences. Techniques and case studies," Ankara: Political Publication, 2014.

[17] A. Yıldırım and H. Şimşek, "Qualitative research methods in social sciences," Ankara: Seçkin Publication, 2016.

[18] M. D. LeCompte and J. P. Goetz, "Problems of reliability and validity in etnographic research," Review of Educational Research, vol. 52, pp. 31-60, 1982.

[19] M. Clark, D. Ensminger, C. Incandela and H. Moisan, "Reflections on museums as effective field sites for teacher candidates," journal of museum education, vol. 44, no. 4, pp. 329-340, 2016.

[20] S. Yılmaz and Ş. Egüz, "History and social studies teachers' experiences and thoughts about the importance of museum in history teaching," Turkish Studies, vol. 11, no. 10, pp. 1637-1650, 2015.

[21] G. E. Hein, "Learning in the museum," London: Routledge, 2002.

[22] S. Das, "Using museum exhibits: An innovation in experiential learning," College Teaching, vol. 63, no. 2, pp. 72-82, 2015.

[23] G. Öner, "Examination of the opinions of social studies teachers about outdoor history teaching," Turkish History Educational Journal, vol. 4, no. 1, pp. 89-121, 2015.

[24] V. A. Jensen, "Museum education and professional development partnerships: How the educational programs of museums enhance career goals and professional development skills in adults," (Master's Thesis), Retrieved from: https://scholarship.shu.edu/theses/246, 2010.

[25] S. Aktekin, "The opinions of the museum experts about the visits of the schools for educational purposes," Ahi Evran University Journal of Kırşehir Faculty of Education (KEFAD), vol. 9(2), pp. 103-111, 2008.

[26] E. Şar, T. Sağkol and Üzerine, "On the necessity of museum education course in education faculties," AY HAYEF: Journal of Education, vol. 10, no. 2, pp. 83-90, 2013.

[27] E. Yildırım, "Opinions of prospective classroom teachers about the use of museums in education," HAYEF: Journal of Education, vol. 14, no. 2, pp. 113-129, 2017.

[28] L. D. Thompson and A. Tobin, "ArtInSight: A contemplative approach to museum gallery teaching and learning," Journal of Museum Education, vol. 43, no. 4, pp. 334-341, 2018.

[29] Z. Dere, "Investigation of the effect of drama on preservice teachers' communication skills," Başkent University Journal of Education, vol. 6, no. 1, pp. 59-67, 2019.

[30] S. Oruç and B. N. Altın, "Museum education and creative drama," Çukurova University Journal of Education Faculty, vol. 3, no. 5, pp. 125-141, 2008. 